\title{
STKS:N 90-VUOTISJUHLAVUOSI: VIREÄÄ TOIMINTAA JA KIINNOSTAVIA TAPAHTUMIA
}

Vuosi 2019 oli Suomen tieteellisen kirjastoseuran juhlavuosi:

90-vuotista taivalta muistettiin historiikilla ja juhlaseminaarissa käännettiin katse kohti tulevaisuutta. Seuran työryhmien järjes-

tämät tapahtumat ajankohtaisista teemoista täydensivät monipuolista vuotta.

$\mathrm{S}$ euramme vuoden 2019 toimintaa leimasi 9o-vuotisjuhlavuoden juhliminen eri tavoin. Kohokohtana oli Tuula Ruhasen ja Marja Sarvilinnan toimittama seuran historiikki Muutoksentekijät hyvässä seurassa - Suomen tieteellinen kirjastoseura I970-2010, joka julkistettiin 27. helmikuuta 20I9. Historiikki on läpivalaisu seuramme toiminnasta ja kattava tietopaketti tieteellisten kirjastojen kehityksestä.

Kesäkuussa järjestimme yhteistyössä Helsingin yliopiston kirjaston kanssa professori Riaan J. Rudmanin sosiaalisen median hyötyjä ja uhkia käsittelevän vierailuluennon $A n$ analogy researcher in a digital (2.0) world.

Juhlavuoden päätökseksi järjestettiin syyskokouksen yhteydessä juhlaseminaari otsikolla Hyvässä seurassa hyvään tulevaisuuteen. Seminaarin kes- keisenä teemana oli tulevaisuuden osaamistarpeet tieteellisissä kirjastoissa. Kansainväliset keynote-puhujat seminaarissamme olivat Ronan O'Beirne (Southamptonin yliopisto) ja Heli Kaatrakoski (The Open University of Arts and Sciences). Kotimaista asiantuntemusta edusti koneoppimisen ja tekoälyn apulaisprofessori Dorota Glowacka Helsingin yliopistosta.

Karl-Erik Henrikssonin juhlarahasto jakoi omana juhlavuotenaan useita apurahoja, joista seuramme jäsenille kohdistettiin I 3 apurahaa. Erityisesti maininnan arvoinen on asiakaspalvelutyöryhmälle myönnetty avustus tutustumisretkeen Tukholman tieteellisiin kirjastoihin. Kansainvälinen verkostoituminen on erityisasemassa työryhmiemme laadukkaan täydennyskoulutuksen tuottamisessa. 
Seuran työryhmät järjestivät syksyllä paljon koulutustilaisuuksia, lokakuussa järjestettiin peräti kaksi seminaaria. Tutkijapalvelu- ja juridiikkatyöryhmät järjestivät ajankohtaisen yhteisseminaarin Tietosuoja, data ja avoimet oppimateriaalit - mitä näistä pitäisi tietää?

Aineistojen saatavuus- ja asiakaspalvelutyöryhmät järjestivät seminaarin Pysy pinnalla - navigointitaitoja kirjastoille. Seminaarissa perehdyttiin aineistojen vaihtoehtoiseen saatavuuteen, tutustuttiin uusiin kirjastojärjestelmiin ja niiden ominaisuuksiin käytännössä ja kuultiin Varastokirjaston kehittyvistä palveluista uuden kirjastojärjestelmän myötä.

Marraskuussa informaatiolukutaito-työryhmä järjesti seminaarin Verkon armoilla vai pedagogiikan pauloissa. Seminaarin aiheita olivat muun muassa etä- ja hybridiohjauksen hyvät käytänteet, opetuksen flippaaminen (flipped classroom) ja saavutettavuus.

Tätä kirjoittaessa etätöissä koronakriisin keskeltä voin todeta, että sTKs:n työryhmät osaavat hienosti pureutua ajankohtaisiin teemoihin ja tulevaisuuden osaamistarpeisiin. Poikkeusolosuhteet ovat saaneet aikaan valtavan opetuksen ja tutkimuksen digiloikan, mikä on tuonut mukanaan lisäkysynnän kirjastojen asiantuntemukselle. Tilanne on tullut meille kaikille yllättäen ja poikkeuksellisen nopealla aikataululla.

\section{Strategian toteutus hyvässä vauhdissa}

STKs:n hallitus arvioi nykyisen vuonna 2017 hyväksytyn strategian toteutumista ja totesi sen olevan ajantasainen ja että sen toteuttaminen on hyvässä vauhdissa (ks. strategia: https://www. stks.fi/wp-content/uploads/20 I 7/os/ sTKs-Strategia.pdf).

STKS, Kansalliskirjasto ja Suomen kirjastoseura laativat yhdessä esityksen Kai Ekholmin huomioimisesta ansiokkaasta työstä IFLAn sananvapauskomitea FAIfEn toiminnassa. Kai Ekholmille myönnettiin IFLAn kunniamitali vuoden 2019 IFLA WLIC -konferenssin yhteydessä.

STKs teki Suomen kirjastoseuran kanssa yhteistyötä myös IFLAn hallituksen edustajan esittämisessä. IFLAn hallitukseen nimettiin asiakkuusjohtaja Minna von Zansen Celiasta. Saimme myös iloita Suomalaisen Kirjallisuuden Seuran kirjastonjohtajan Heli Kautosen valinnasta LIBERin hallitukseen.

Keskustelu avoimesta tieteestä ja sen vaikutuksista tutkimuksen ja tutkimusta tukevien palveluiden kehitykseen on lisääntynyt entisestään.

IFLAn pyynnöstä seura laati yhdessä Suomen kirjastoseuran kanssa vetoomuksen, joka koski kirjastojen tekijänoikeuslakipoikkeuksia. Vetoomus osoitettiin IFLA WLIC -kokoukseen osallistuneille opetus- ja kulttuuriministeriön edustajille. Seura antoi vuonna 2019 myös lausuntonsa avoimen tieteen kansallisen strategian luonnoksesta. 
Jäsenhankinta kaipaa

\section{vauhdittamista}

Seuran jäsenmäärä oli vuonna 2019 edelleen laskussa; vuoden alussa seuralla oli 520 henkilöjäsentä, mutta loppuvuodesta jäsenmärä tippui alle viidensadan. Lasku on seurausta alan työntekiiöiden vähenemisestä: korkeakoulu- ja erikoiskirjastosektoreiden työpaikat vähenevät kehysorganisaatioiden rahoituksen heikennyttyä. Kirjastoja on yhdistetty ja tietopalveluita ajettu alas. Toimintavuoden aikana tehtiin myös jäsenrekisterin tarkistus ja rekisteristä poistettiin ne jäsenet, jotka eivät ole maksaneet jäsenmaksuaan kolmeen vuoteen.

Jäsenmäärän kehityksellä on suoria vaikutuksia seuramme talouteen. Tänä vuonna etsimmekin säästöjä muun muassa pienentämällä Signumin painosmäärää ja siirtymällä osin hallituksen etätapaamisiin. Seuran hallinnon ja sisäisen yhteydenpidon tehostamiseksi otimme käyttöön Google Suite -työskentely-ympäristön ja stks.fi-loppuiset sähköpostiosoitteet. Jäsenhankinnan vauhdittamiseksi laadittiin uusi markkinointiesite, joka toistaa seuran verkkosivujen uudistettua visuaalista ilmettä.

Etsimme edelleen keinoja tasapainottaa seuran taloutta ja turvata toiminnan jatkuvuuden vakaana myös tulevina vuosina. Jokainen uusi jäsen on lämpimästi tervetullut joukkoom- me ja toivon, että myös jäsenet kannustavat alalle tulevia liittymään seuraan.

\section{Uusia tuulia}

Juhlavuosi toi mukanaan uudistuksia seuran työryhmiin. Erikoiskirjastojen työryhmä lakkautettiin erillisenä ryhmänä. Jäsenemme erikoiskirjastoista ovat aktiivisesti mukana seuran muissa työryhmissä. Uutena työryhmänä päätettiin perustaa uuden teknologian työryhmä, joka aloittaa toimintansa 2020.

Myös seuran toimihenkilöissä tapahtui vaihdoksia. Uudeksi taloudenhoitajaksi valittiin Tarja Hämäläinen. Myös Signumin päätoimittaja vaihtui ansiokkaasti Signumia luotsanneen Johanna Lahikaisen luovuttua tehtävästä. Uudeksi päätoimittajaksi valittiin Juuso Ala-Kyyny. Juuson kädenjälki on jo näkynyt uusimmissa numeroissa. Seura myös päätti laajentaa Signumin entisen toimitusneuvoston toimitusverkostoksi; toiveena on saada Signumiin monipuolisesti kirjoituksia eri kirjastosektoreilta maanlaajuisesti.

Juhlavuosi oli vaiherikas ja monipuolinen - kiitos kuuluu seuran hallitukselle, toimihenkilöille, työryhmille ja etenkin teille jäsenille, jotka mahdollistatte seuran toiminnan. Nyt on aika kääntää katse tulevaan ja tähyillä kohti Ioo-vuotisjuhlintaa.

\section{PäLvi KaIPONen}

Helsingin yliopiston kirjasto palvi.kaiponen@helsinki.fi 